\title{
PJIEE
}

Premise : Journal of English Education and Applied Linguistics

https://fkip.ummetro.ac.id/journal/index.php/english

Adara

\section{STUDENTS' MOTIVATION AND PREFERENCES TOWARD NATIVE AND NON-NATIVE ENGLISH SPEAKING TEACHERS}

\author{
by \\ Reza Anggriyashati Adara \\ ENGLISH LANGUAGE AND LITERATURE DEPARTMENT OF ISLAMIC \\ UNIVERSITY'45 BEKASI \\ MATA GARUDA INSTITUTE \\ reza.adara@gmail.com
}

Abstract:

There is a notion that teachers are one of important factors which motivate students to learn English. The present study aims to investigate students' motivation in learning English with Native English Speaking Teachers (NEST) and Non-native English Speaking Teachers (NNEST) and whether the students are more motivated to learn English with NEST or NNEST. Furthermore, this study examines students' preferences regarding NEST and NNEST. To obtain the findings, mixed method research was conducted. A set of questionnaires were distributed to thirty students in a private junior high school in Bekasi, Indonesia whereas semi-structured interviews were conducted to two students of same school. The findings show that teacher is an influential factor that motivates students to learn English. Although the respondents are more motivated to learn English from NEST, they do not have certain preferences regarding NEST and NNEST as both teachers help the respondents to learn English in different ways. The findings reveal that NEST are considered better in vocabulary teaching while NNEST teach grammar better.

Key words: foreign language learning, motivation, NEST, NNEST, students' preferences.

\section{INTRODUCTION}

One of significant factors which influence students to learn foreign language is motivation. In this regard, motivation refers to a combination of efforts, desires, and attitudes to reach the objective of language learning (Loewen and Reinders, 2011; Gardner, 2005; Dörnyei and Ottó, 1998). The significance of motivation is due to its position as the primary drive in foreign language learning and to sustain learners' interest during tedious driving force (Dörnyei, 1998). Similar statement is mentioned 
by Gardner and Lambert (1972) who emphasised the importance of motivation over language aptitude. Gardner and Lambert (1972) pointed out certain language environments where many people master foreign language regardless the differences in their language aptitude. The weight of evidence suggests the importance of motivation in foreign language learning.

Teacher can be considered as one of influential factors to motivate students to learn foreign language. Several studies have discussed the correlation between teachers and students' motivation in foreign language learning. Ryan and Deci (2000) suggest that students are more willing to participate in the classroom if they feel respected or cared by teachers. Although teachers might not influence on students' internal motivation significantly (Lightbown and Spada, 1999), teachers are argued as the most powerful variable in students' motivation and demotivation (Harmer, 1991). A study of Gardner and MacIntyre (1993) suggests that besides instructional aid and curricula, teachers have an effect on how learners react to the teaching experience. It can be said that students' motivation in learning foreign language learning depends on teachers.

There is an argument that students prefer NEST to NNEST. In this regard, native speakers refer to people who use the language as their first or native language (Davies, 1991) whereas non-native speakers can be defined as "speakers of language that is not their L1" (Boecher, 2005: 68). It is argued that native speakers can provide the best model of language. The ideal position of native speakers as language models has been claimed by Chomsky (1965). As a result, there is a notion that NEST are preferable among students. The aforementioned point has been discussed in some studies. A study of Lagabaster and Sierra (2005) show a preference over NEST among students. Besides the previous study, the findings of Diaz's (2015) study also show students' preferences to NEST. However, the findings of other studies show otherwise. Arvizu's (2005) study reveals that students do not have certain preference to certain type of teachers. The findings of Madrid and Cañado, (2004) also show similar conclusion with Arvizu's (2005) study. On the other hand, the study of Agudo and Robinson do not suggest any students' preferences regarding NEST and NNEST. It can be said that the argument of students' preferences to NEST over NNEST is still debatable.

However, Native English Speaking Teachers (NEST) have been argued as better language models than Non-native English Speaking Teachers (NNEST). The argument 
is in line with Chomsky's (1965) claim that native speakers are the ideal speakers of the language. Furthermore, there are other factors such as a claim that language competence of native speakers cannot be achieved by non-native speakers (Medgyes, 1992) and a long tradition to respect native speakers in foreign language teaching, applied and pure linguistics which borders on devotion (James, 1998). As a result, native speakers have been traditionally preferred as language teachers (Pae, 2016). A study of Lagabaster and Sierra (2005) reported a preference to NEST in some countries such as Japan and Korea. However, the notion of native speakers as better language models have been challenged in some studies (Canagarajah, 1999; Kramsch, 1997; Medgyes, 1992). Lee (2005) argued that some elements, such as linguistic and cultural competence that a native speaker knows, can be acquired by non-native speakers through learning and teaching principles. Lee's argument is supported by Phillipson (1992) whom considered the belief of native speakers as the best language models as native speaker fallacy. It can be said that NNEST can be as good as NEST in regards of being ideal language models.

Although NNEST could be good language models as NEST, there is a preference among students to NEST over NNEST. Some studies have investigated students' preferences regarding NEST and NNEST (Diaz, 2015; Lagabaster and Sierra, 2002; Madrid and Cañado, 2004). The findings of Lagabaster and Sierra's (2002) study indicated the preferences to NEST among university level students whereas Takada's (2000) findings suggested that the parents doubt the teaching ability of NNEST and prefer NEST to teach their children. It can be said that some students have certain preferences over NEST to NNEST.

In spite of extensive research on students' preferences regarding NEST and NNEST, there is lack of studies which investigated both students' motivation and preferences in learning foreign language with NEST and NNEST. The study of Pae (2016) discussed the differences in students' motivation and attitudes in learning English with NEST and NNEST. The theme of Pae's (2016) study is quite close to the present study. Besides students' motivation and attitudes, Pae (2016) investigated the differences in students' perceptions toward NEST and NNEST. Furthermore, he examined how the differences in students' perceptions affect their motivation and attitudes toward NEST and NNEST. To obtain the results, Pae used a quantitative 
method by distributing two sets of questionnaire to 39 teachers and 747 students. The questionnaire used by Pae was adapted from SDT (Self-Determination Theory) of Deci and Ryan (2000). Pae research can be considered as a big scale research due to the number of respondents. The findings show significant differences in students' attitudes and motivation when they learn English with NEST and NNEST. Majority of students felt more motivated and showed more positive attitudes when they learn English with NEST.

On the other hand, the study of Díaz (2015) examined students' preferences toward NEST and NNEST. Although the study of Diaz (2015) did not discuss students' motivation in learning English, it examined students' preferences regarding NEST and NNEST. To examine the matter, Diaz used a quantitative method. A questionnaire, which was adapted from Lagabaster and Sierra's (2002) questionnaire about students' preferences on NEST and NNEST, was distributed to 78 university students in France. The findings revealed students' preferences to NEST over NNEST. However, Diaz noted that majority of students prefer or choose both teachers for teaching certain subjects such as grammar, culture, strategy and vocabulary learning.

A study which investigates a correlation between students' motivation and students' preferences regarding NEST and NNEST is worth to be conducted as it will provide more insights to the matter. The aim of current study is to investigate whether students are more motivated to learn English with NEST or NNEST. Besides that, this study will examine whether students' motivations lead to preference over NEST or NNEST. Specifically, this study is guided by following research questions.

1. Which factors motivate students to learn English?

2. Do teachers influence students' motivations to learn English?

3. Do students feel more motivated to learn English with NEST or NNEST?

4. Do students have certain preferences regarding NEST or NNEST?

\section{METHOD}

\section{Design}

Premise Journal Vol 7 No 1, April 2018, e-ISSN: 2442-482x, p-ISSN: 2089-3345, page:1-21

Copyright@2018 by PJEE 
This study applied a mixed-method approach which combines quantitative and qualitative approaches to obtain the findings. A mixed-method approach was chosen as it would provide more insights to the research's discussion due to the combination of methods. Despite the argument toward the effectiveness of mixed method approach as it might undermine obtained findings due to lack of focus to each approach (Symonds and Gorand, 2010), a more comprehensive understanding toward a complex phenomenon can be obtained due to the approach (Condelli and Wrigley, 2004). Due to the complex nature of present study, a mixed method seems suitable to obtain the comprehensive findings for this study.

\section{Participants}

The participants of this study are 32 junior high school students from a private school in Bekasi, Indonesia. The school was chosen as it provides English lessons from both NEST and NNEST. 60\% respondents of this study were girls whereas $40 \%$ of participants were boys. Following is the chart which describes the sex of respondents.

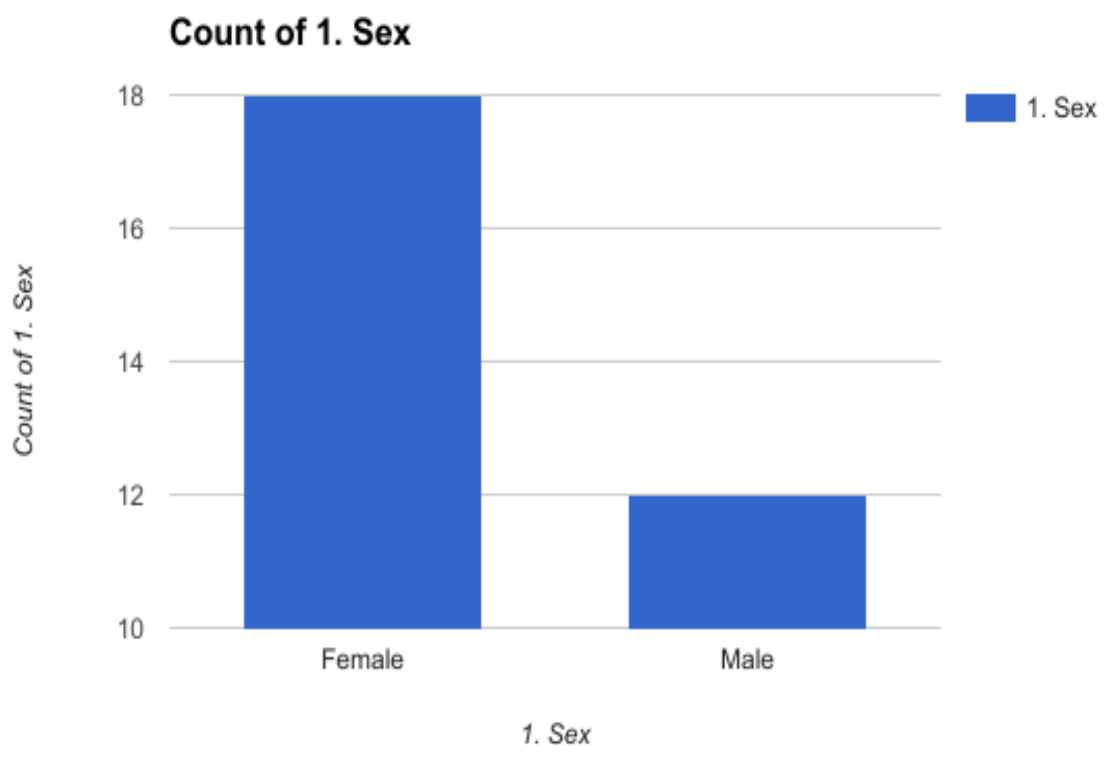

Figure 3.1. The sex of respondents

Due to the number of participants, the study can be considered as a small scale study. Regarding the number of respondents, there is an argument that it may affect the validity of research findings. Similar statement has been mentioned by Nulty (2008) whom argued the representation of the whole group of students. However, Mason 
argued that large scale data do not always influence the effectiveness of a research (2010) as it depends on "the nature of the topic, the quality of the data [and] the study design" (Morse, 2000: 4). Based on previous points, the number of respondents seems sufficient for the study.

\section{Data Collecting Technique}

Two research instruments were applied for this study; questionnaires and interviews. A set of questionnaires with twenty questions were given to thirty private junior high school students in Bekasi, Indonesia. The questionnaires (see Appendix 1) were adapted from Gardner's (1985) AMTB or Attitude/Motivation Test Battery. The questionnaires are divided into two parts. First part is an open-ended one about the participant's gender and time they spent to learn English. The second part is adapted from Gardner's (1985) AMTB or Attitude/Motivation Test Battery. Unlike Gardner (1985), the present study only uses four response-options for the Likert scale.

- Strongly disagree.

- Disagree.

- Agree.

- Strongly agree.

Besides questionnaires, the present study applied interviews which were conducted to two students from the same school. The transcript of interviews can be seen in Appendix 2.

\section{RESULTS AND DISCUSSIONS}

This section will discuss the results of the present study. The first sub-section will analyze students' motivation in learning English and whether teachers are significant factors which motivate them to learn English whereas students' preferences regarding NEST and NNEST were discussed in the next sub-section. The last subsection aims to discuss the limitations of the present study and possible studies.

\section{Students' motivation in learning English}


This sub-section aims to discuss findings related to students' motivation in learning English. There are two kinds of motivational factors in foreign language learning; intrinsic and extrinsic factors. In this sense, intrinsic factors refer to beliefs that are related to language learning (Madrid, 1995: 65) while extrinsic factors can be described as ones influenced by variables such as school, peers, or teachers (Lamb, 2007: 78). Hence, the earlier discussion in this sub-section will focus on those factors. After that, the discussion will be continued to type of teachers (NEST or NNEST) which motivated the participants the most to learn English.

\section{Intrinsic Factors}

Following charts are the findings which related to intrinsic factors of participants' motivation to learn English.

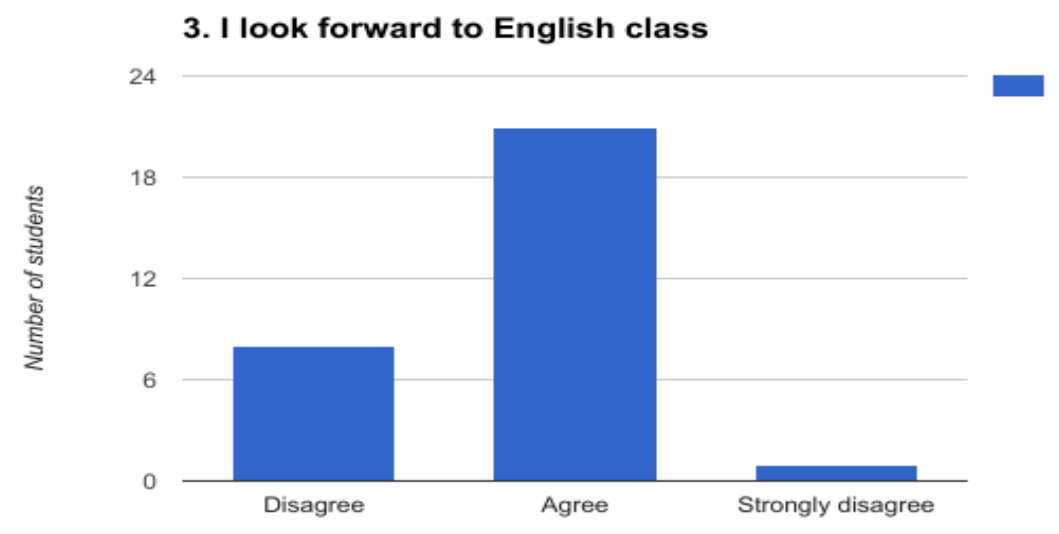

Figure 4.1 
4. English is one of my favourite courses.

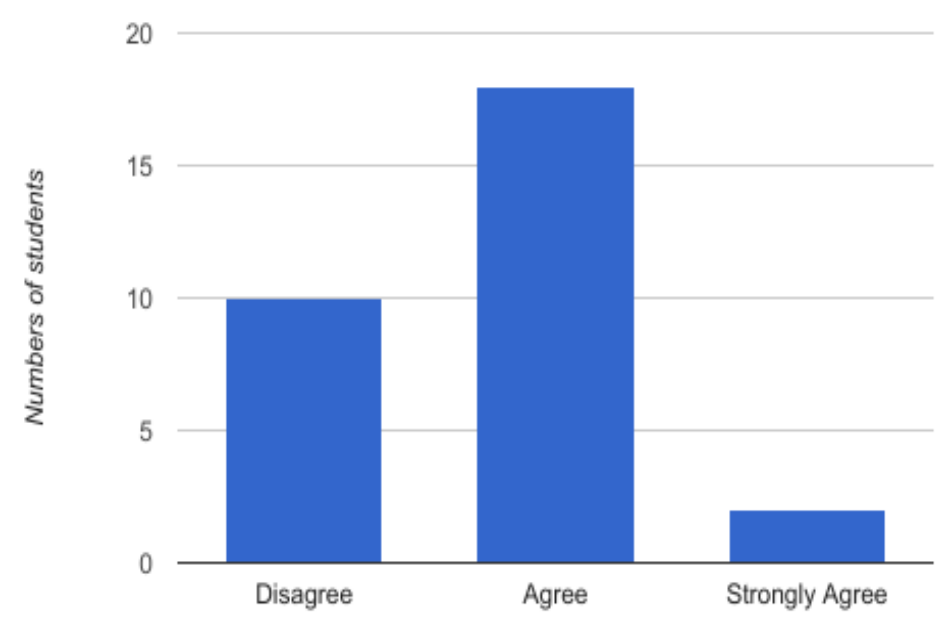

Figure 4.2

8. I plan to learn English as much as possible.

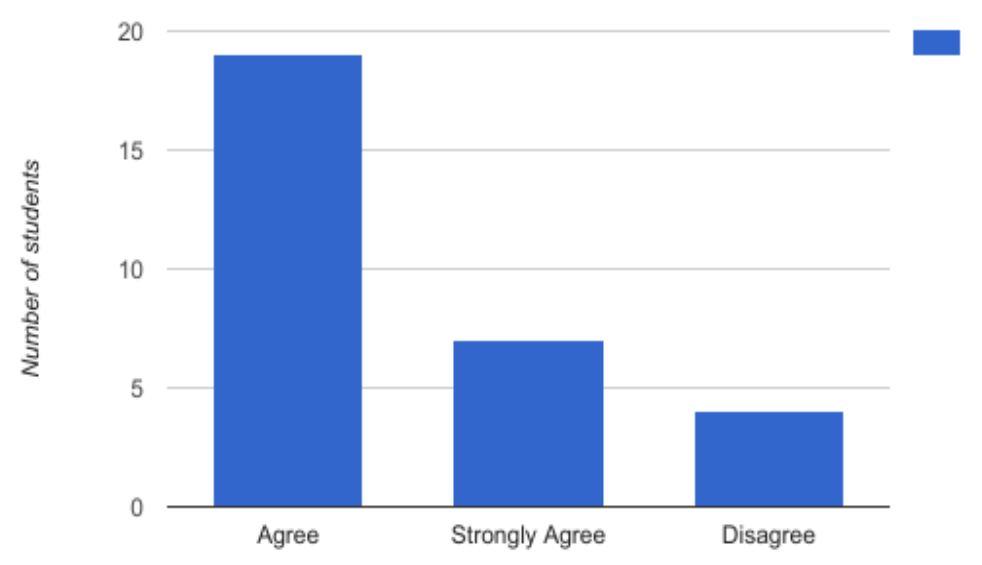

Figure 4.3

Figure 4.1 shows that 22 out of 30 participants agreed with the statement. Similarly, figure 4.2 shows that 20 participants out of 30 agreed with the statement. Figure 4.3 shows that 25 participants out of 30 opted 'agree' option. The findings of above items suggest intrinsic factors as ones that motivate majority of participants to learn English. The above findings were quite different with the findings from the study of Moskovsky and Alrabai (2009) which investigated levels of intrinsic motivation of 
English learners in Saudi Arabia. Based on the findings of their study, Moskovsky and Alrabai (2009) concluded average level of intrinsic motivation among the participants.

\section{Extrinsic Factors}

Following are findings related to extrinsic factors of participants' motivation to learn English. The findings will be described before discussed.

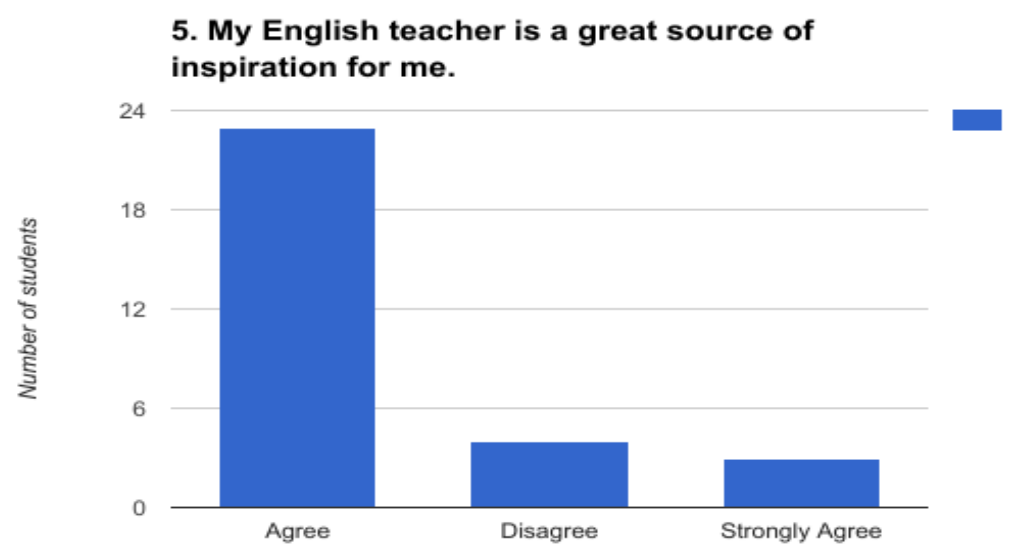

Figure 4.4

6. My parents influence me to learn English.

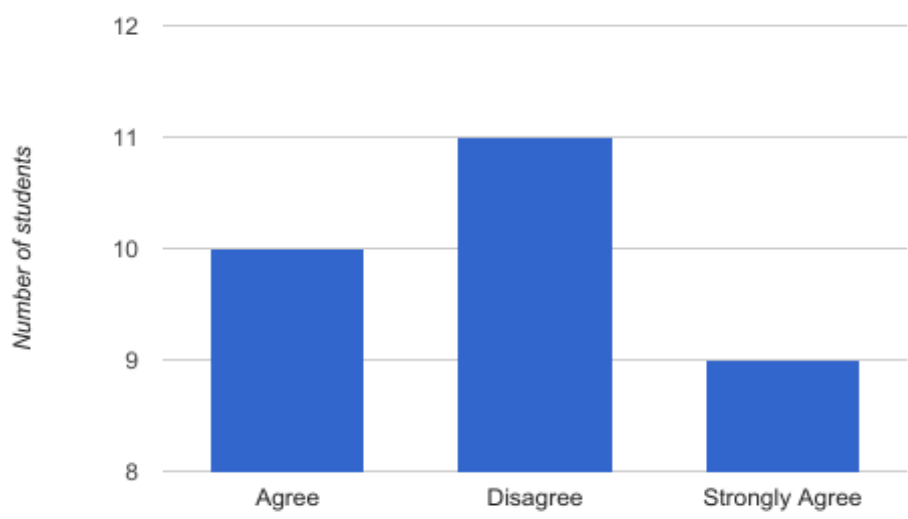

Figure 4.5

Premise Journal Vol 7 No 1, April 2018, e-ISSN: 2442-482x, p-ISSN: 2089-3345, page:1-21

Copyright@2018by PJEE 


\section{I learn English to get better jobs.}

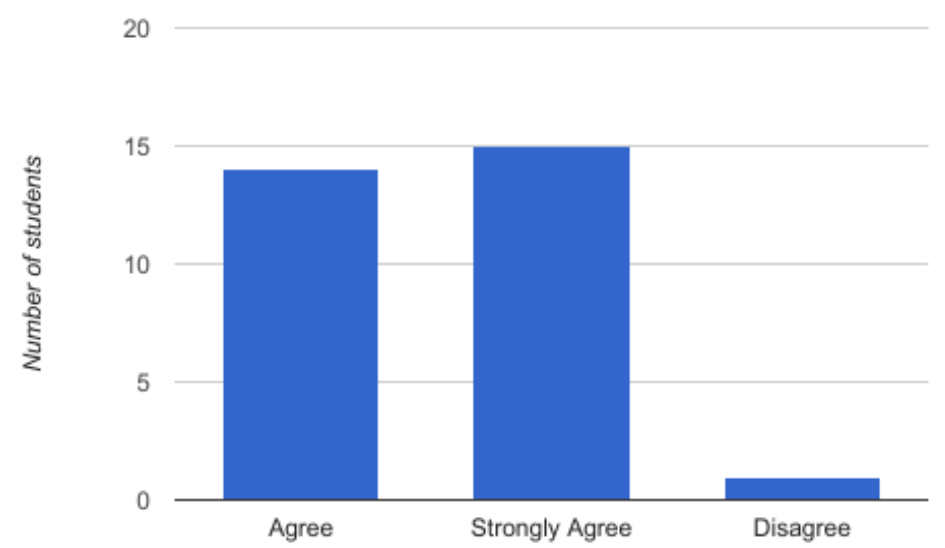

Figure 4.6

Findings of figure 4.4 show 26 out of 30 participants agreed with the statement whereas figure 4.5 shows 19 out of 30 participants agreed that their parents influenced them to learn English. Figure 4.6 shows that 29 out 30 participants agreed with the statement. The findings of above items imply that participants are aware that extrinsic factors such as teachers, parents, and chances of getting better jobs can influence them to learn English. Besides that, the findings imply that chances of getting better jobs as the factor which influence them most to learn English. The findings were quite similar to Khazaie and Mesbah's (2004) study on Iranian learners which suggests getting a job as an extrinsic factor to study English. Although it is not as influential as getting better jobs, the findings of the present study suggest English teachers as extrinsic factors which motivate most students to learn English. The results are quite similar to Lamb's (2007) study toward motivation of a group of junior high school students in Indonesia to learn English. Lamb's (2007) findings implied teachers and peers as extrinsic factors which motivated students to learn English.

The findings of above items suggest teachers as one of motivational factors of learning English. Furthermore, certain types of teachers seem to be more motivating to students. The findings of following item suggest the aforementioned idea; 


\section{I would be more motivated to study English \\ if my teacher is a native speaker.}

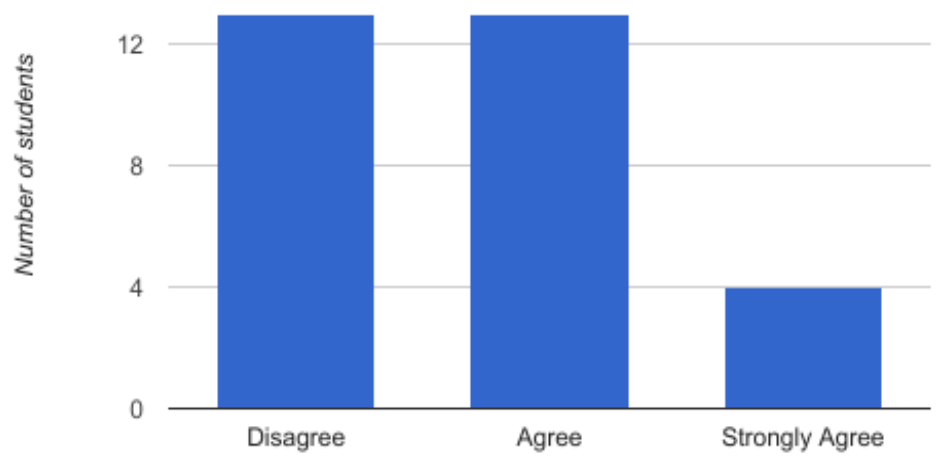

Figure 4.7

Figure 4.7 shows that 17 out of 30 participants agreed with the statement. The findings suggest that most participants think studying English with NEST is more motivating than with NNEST. The findings of Pae's (2016) study also share similar results with the present study. The participants of Pae's (2016) study perceived studying English from NEST as more motivating. Besides that, Pae's participants who studied English from NEST showed greater practical and intrinsic value of learning English than ones who studied English from NNEST. On the contrary, the participant of this study suggests that studying English from NEST might not always make students understand English better. Following comment is mentioned by Student B:

"I think, [studying English from NEST] no, [always make me understand English] because a lot of students respect the non-native teachers speakers more than the native speakers...sometimes when the non-native teacher is teaching, they're like quiet and they're afraid if their teacher will be mad if they talk but when it's native teacher, they just like talk and eat and walk everywhere because it's not your teacher, it's just the native speaker so you kinda have less respect..."

The above comment implies that studying English from NEST does not always lead to more motivating condition in the classroom as students respect NNEST more than NEST.

\section{Students' preferences regarding NEST and NNEST}

Premise Journal Vol 7 No 1, April 2018, e-ISSN: 2442-482x, p-ISSN: 2089-3345, page:1-21 
Below are findings related to students' preferences regarding NEST and NNEST? The findings will be described before analyzed with findings of previous studies.

11. I would prefer a native speaker as a teacher.

20

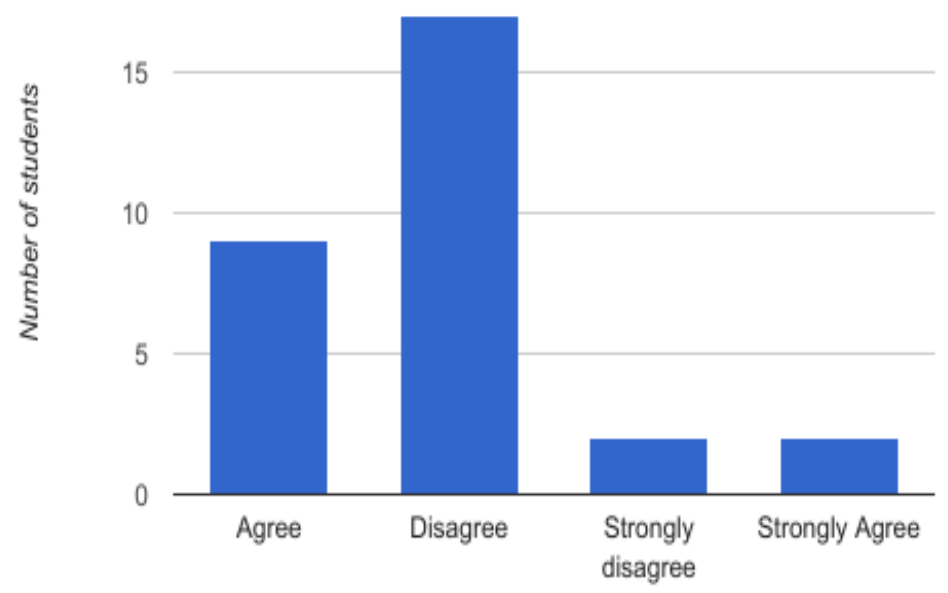

Figure 4.8

18. Studying English is more fun with native teachers.

20

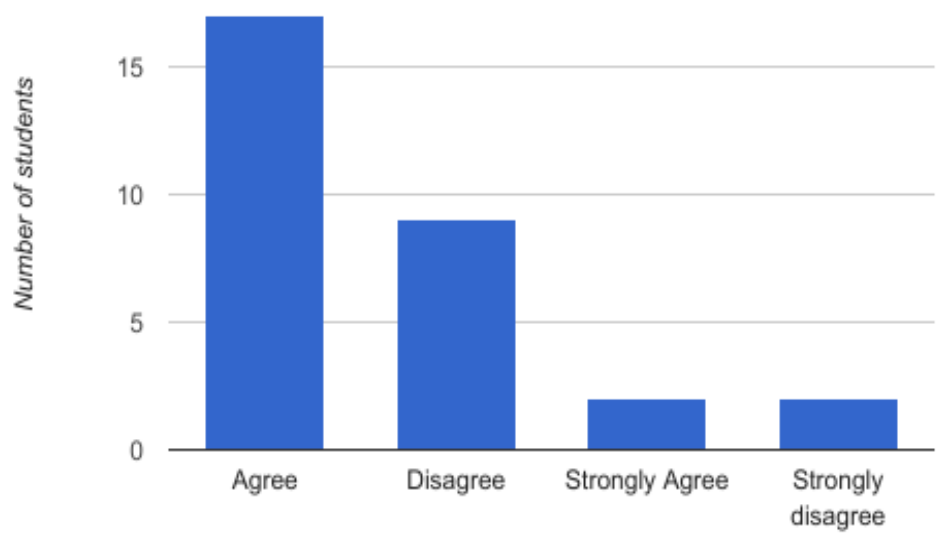

Figure 4.9

Premise Journal Vol 7 No 1, April 2018, e-ISSN: 2442-482x, p-ISSN: 2089-3345, page:1-21

Copyright@2018by PJEE 


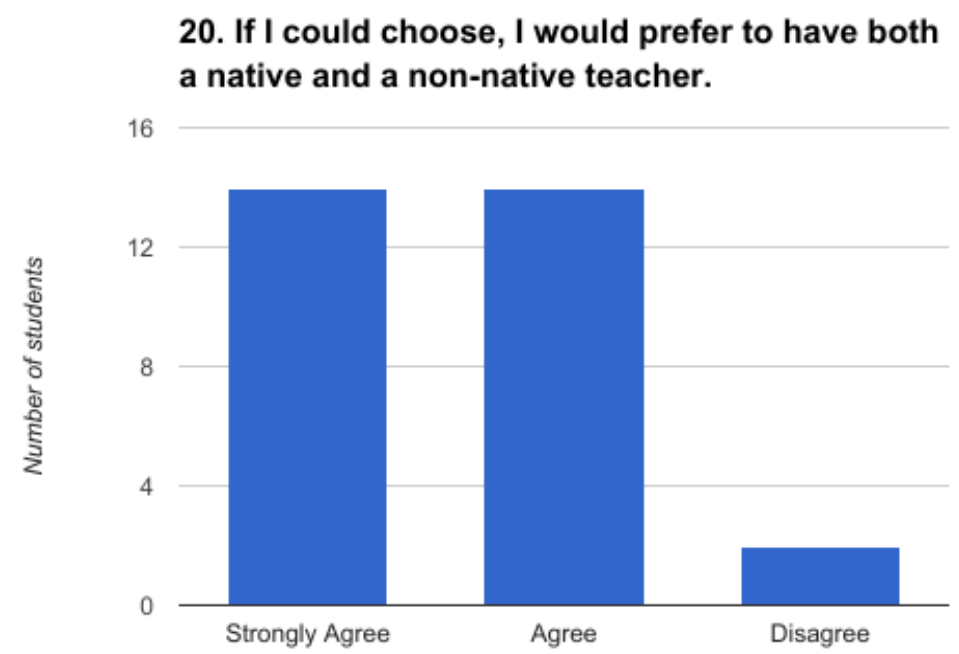

Figure 4.10

Figure 4.8 shows 19 out of 30 participants opted for 'disagree' option whereas figure 4.9 shows 19 out of 30 participants agreed with the statement. Figure 4.10 shows 28 out of 30 participants agreed with the statements. The findings of figure 4.8 suggest that majority of participants prefer NNEST to NEST. Besides that, students' preferences to NNEST were also shown from following comment;

"I think...(I like) non-native speakers (better)." (Student A)

The results are quite different from the findings of Diaz's (2015) study which indicated students' preferences to NEST. The findings of Lagabaster and Sierra's (2005) study also implied students' preferences to NEST. However, the findings of figure 4.9 imply that students think learning English from NEST as more fun. Besides that, the findings of figure 4.8 also do not imply any students' preferences to certain teachers that participants prefer to be taught by both teachers. Following comments from Student B also suggest neutral preferences;

"Umm...I...have no preference but, when native teachers teach you, sometimes the translator [interpreter] doesn't understand either." (student B)

In Student B's context, English lessons with NEST are always accompanied by interpreters that sometimes translate difficult English spoken by NEST to Bahasa Indonesia. Due to language hindrance, students tended to be reluctant to ask NEST. The results of those items suggest neutrality of students' preferences. The findings of Madrid and Cañado's (2004) study also indicated neutral preferences over NEST or 
NNEST among students whereas the findings of Madrid and Cañado's (2004) study implied insignificant preferences to NEST among students in higher levels.

Students might have reasons for their preferences to certain teachers. Following are comments from both participants regarding their preferences and the reasons behind them.

"I like [being taught by NEST], but sometimes...umm, not all students understood what he's talking about but they're too afraid to ask him so they ended up not knowing anything."

"I prefer native speakers, if everyone understood." (Student B)

"Because...umm....when I don't understand the language err the vocabulary."

"Oh...I can ask (the meaning of words) with Indonesian language." (Student A)

Both participants seem to prefer NNEST due to the shared L1. When they don't understand something in English, having NNEST can be more convenient than NEST because students can ask the question using their shared L1. Nevertheless, they seem to like having both NEST and NNEST as mentioned by Student B, "Both of them help in different ways." Student B elaborated that in following comment,

"...native speakers teach you how to spell the words and your teachers teach you what's like the grammar...." ( student B)

Student B thinks NNEST teach grammar better whereas NEST teach pronunciation better. Besides Student B's comments, following findings also suggest students' preferences to NEST in vocabulary teaching: 
19. I learn vocabulary better with native teachers.

16

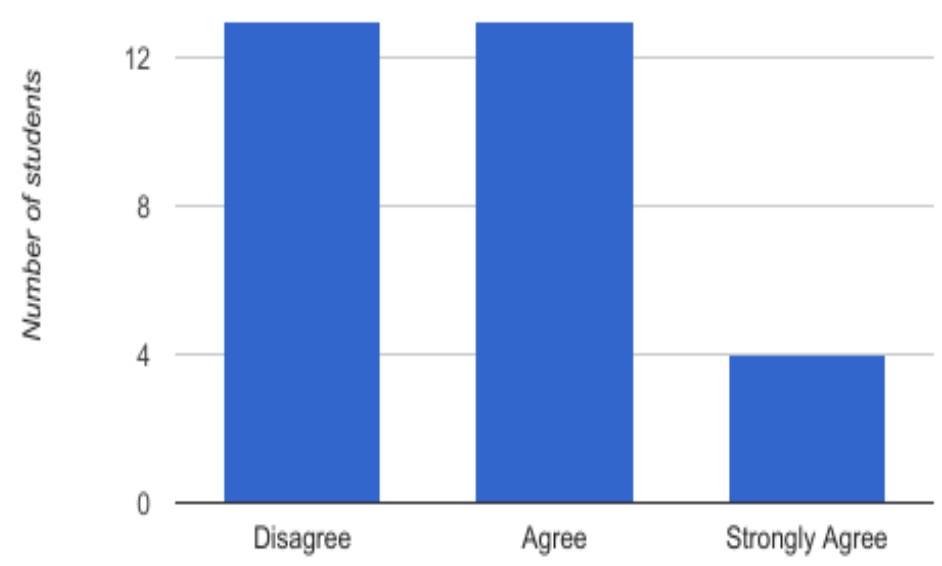

Figure 4.11

13. I would speak more fluently if I had a nonnative teacher.

20

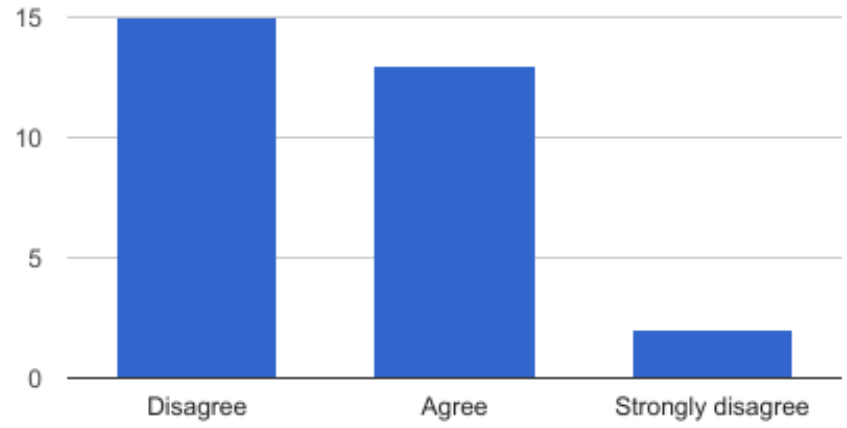

Figure 4.12

Figure 4.11 shows 17 out of 30 participants agreed with the statement whereas figure 4.12 shows 17 out of 30 participants opted for 'disagree' option. The findings of both items suggest students' preferences to NEST in vocabulary and pronunciation teaching. Diaz's (2015) study also showed students' preferences to NEST in pronunciation teaching. Similar results were also shown in the studies of Lagabaster 
and Sierra (2005). This perception might be caused by idea that native speakers are more fluent and knowledgeable in cultural facts (Braine, 1999). On the other hand, NNEST seem to be preferred to teach grammar. Following figure shows the participants' preferences to NNEST in grammar teaching:

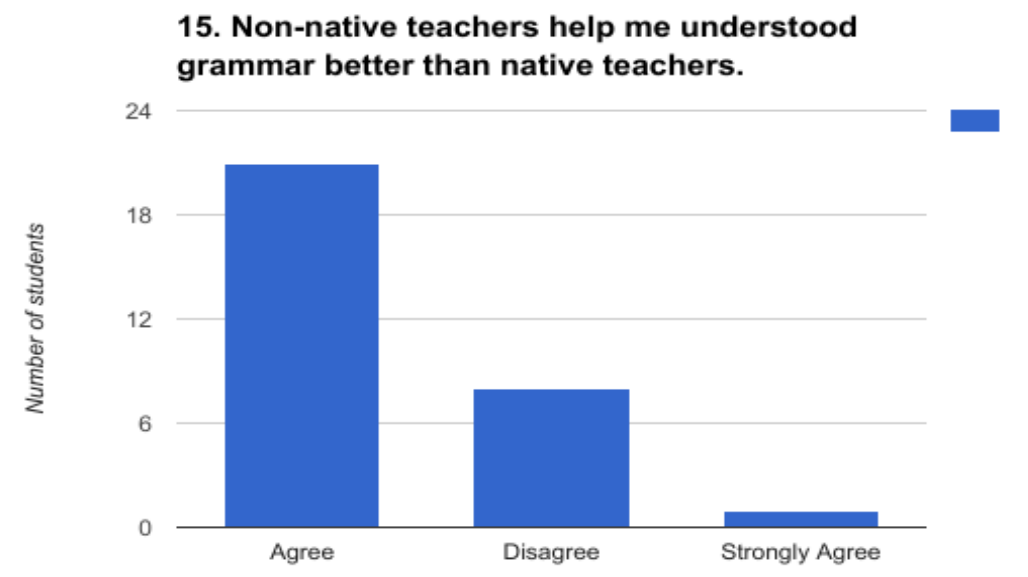

Figure 4.12

Figure 4.12 shows 22 out of 30 participants agreed with the statement. The findings imply that participants prefer NNEST in grammar teaching to NEST. The study of Mahboob (2004) shows students' preferences to NNEST in strategies teaching. In this study, the participants might see the benefits of being taught by both teachers. This might lead to their neutral preferences regarding NEST or NNEST.

\section{Implications and limitations}

Generally, the present study may be able to provide more insights on students' motivation in learning foreign language as well as students' preferences regarding NEST and NNEST. Specifically, this study might help to give more information toward the motivation and preferences of foreign language learners in Indonesian context. Thus, this study might help other researchers whom are interested to investigate foreign language learners in Indonesia. The present study can be considered as a stepping stone for a bigger scale research in students' motivation and preferences regarding NEST and NNEST in Indonesia.

The findings of this study show that teachers as one of influential factors which motivate students to learn English. However, a further research toward the motivational 
effects of teachers on foreign language learning needs to be conducted to investigate the above premise. This might help to provide information for teacher training of foreign language learning, specifically for foreign language teacher training in Indonesia.

Secondly, the results show the neutral preferences of students regarding NEST and NNEST. Students prefer to have both teachers as they consider each teacher is helpful in different ways. However, this study did not compare the effects of NEST and NNEST on students' motivation and preferences. Pae (2016) has investigated the effects of NEST and NNEST on students' motivation in South Korean context. A study which specifically investigates the effects of NEST and NNEST on Indonesian students' motivation might need to be conducted in the future.

However, it is worth noting that the present study is not without some limitations. First is the number of participants. This study might provide better insights with more participants. However, there is no exact number of students who obtain English lessons from both NEST and NNEST in Bekasi. Besides that, some institutions might not allow researcher's access to students. Further studies might obtain better insights if researchers get better access to more participants from diverse levels of language skills. Second is the research instrument. More in-depth findings might be obtained if this study used more research instruments such as classroom observation or learners' journals to record their thoughts or feeling after sessions with either NEST or NNEST.

\section{CONCLUSIONS}

This study examined the students' motivation and preferences in learning English with NEST and NNEST. Specifically, this study investigated the factors which motivate students to learn English as well as students' preferences regarding NEST and NNEST. To investigate the matter, this study applied a mixed method approach by administering two research instruments; questionnaires and interviews. The participants are thirty two students of a private junior high school in Bekasi, Indonesia. They were chosen because they have been taught by NEST and NNEST.

The findings indicated teachers as one of influential factors that motivate students to learn English. Furthermore, the findings imply neutral preferences of students regarding NEST and NNEST. Although majority of participants prefer 
NNEST over NEST due to shared L1, the participants seem to see the benefits of being taught by NEST and NNEST. The participants prefer NEST in pronunciation and vocabulary teaching whereas NNEST are preferred in grammar teaching. The above findings might lead to students' neutral preferences to NEST and NNEST.

\section{BIO-PROFILE}

Reza Anggriyashati Adara, M.A holds her bachelor degree in English Literature and Language from Universitas Islam 45 Bekasi and a master degree in Teaching English as a Second Language from University of Birmingham, the United Kingdom. Her expertises are in Motivation, learner's attitudes, as well as perceptions toward NEST and NNEST. Corresponding email is reza.adara@gmail.com. 


\section{REFERENCES}

Arvizu, M. (2014) Students' Beliefs and Expectations of Native and Non-Native English Teachers, MEXTESOL Journal 38 (3), 1-15.

Boecher, Y (2005) Native and Nonnative English-Speaking Teacher Distinctions: From Dichotomy to Collaboration. The CATESOL Journal 17.1, 67-75.

Braine, G. (1999). Non-Native Educators in English Language Teaching. Mahwah, NJ: Lawrence Erlbaum.

Canagarajah, A. S. (1999). Interrogating the 'native speaker fallacy': Non-linguistic roots, non-pedagogical results. In G. Braine (Ed.), Non-native educators in English language teaching (pp. 77-92). New Jersey: Lawrence Erlbaum Associates.

Condelli, L. and Wrigley, H. S. (2004) Real World Research: Combining Qualitative and Quantitative Research for Adult ESL. Paper presented at NRDC Second International Conference for Adult Literacy and Numeracy. An examination of research to practice initiatives within ESOL literacy.

Davies, A. (1991). The native speaker in applied linguistics. Edinburgh: Edinburgh University Press.

Díaz, N. R ( 2015 ) Students' preferences regarding native and non-native teachers of English at a university in the French Brittany, Procedia - Social and Behavioral Sciences 173, $93-97$

Dörnyei, Z and Ottó, I. (1998). Motivation in action: A process model of L2 motivation. Working Papers in Applied Linguistics (Thames Valley University, London), 4, 43-69.

Dörnyei, Z. (2001). New themes and approaches in second language motivation research. Annual Review of Applied Linguistics, 21, 43-59.

Dörnyei, Z. (2005). The Psychology of the Language Learner: Individual Differences in Second Language Acquisition. Mahwah: Lawrence Erlbaum Associates.

Gardner, R. \& Lambert, W. (1972). Attitudes and motivation in secondary language learning. Rowley: Newbury House.

Gardner, R. C. (1985). Social Psychology and Second Language Learning: The Role of Attitudes and Motivation. London: Edward Arnold.

Gardner, R. C., and MacIntyre, P. D. (1991). An Instrumental Motivation in Language Study: Who Says It Isn't Effective? Studies in Second Language Acquisition, 13, (1), 57-72.

Gardner, R.C. (2005) Integrative motivation and second language acquisition. (Joint Plenary Talk), Canadian Association of Applied Linguistics/Canadian Linguistics Association. 
Guilloteaux, M. J., and Dörnyei, Z. (2008). Motivating language learners: A classroom oriented investigation of the effects of motivational strategies on student motivation. TESOL Quarterly, 42 (1), 55-77.

Harmer, J. (1991). The Practice of English Language Teaching, London: Longman.

Kramsch, C. (1997). The privilege of the non-native speaker. PMLA, 3, 359-369.

James, C. (1998). Errors in Language Learning and Use. Exploring Error analysis. London: Longman.

Lagabaster, D and Sierra, J.M. (2002) University Students' Perceptions of Native and Non-native Speaker Teachers of English. LANGUAGE AWARENESS 11 (2), 132-142.

Lagabaster, D and Sierra, J.M. (2005) The Nativeness Factor: An Analysis of Students' Preferences. ITL - International Journal of Applied Linguistics $147 / 148,21-43$

Lamb, M.V. (2007). The motivation of junior high school pupils to learn English in provincial Indonesia. PhD Thesis. University of Leeds.

Lightbown, P., and Spada, N. M. (1999). How languages are learned. Oxford: Oxford University Press.

Liu, H and Chien-wei C (2015) A Comparative Study of Foreign Language Anxiety and Motivation of Academic- and Vocational-Track High School Students. English Language Teaching 8 (3), 123-204.

Loewen, S. and Reinders, H. (2011). Key Concepts in Second Language Acquisition. Basingstoke: Palgrave Macmillan.

Madrid, D and Cañado, M (2004) Teacher and Student Preferences of Native and Nonnative Foreign Language Teachers. PORTA LINGUARUM 2, 124-138.

Mahboob, A. (2004). Native or Non-Native: What do the Students Think. In L. D. Kamhi-Stern (Ed.), Learning and Teaching from Experience (pp. 121-147). Michigan: University of Michigan Press.

Medgyes, P. (1992). Native or non-native: who's worth more? ELT Journal, 46, 340349.

Morse, J., (2000) Determining Sample Size. Qualitative Health Research, 10 (3), 3-5

Moskovsky, C., and Alrabai, F. (2009). Intrinsic motivation in Saudi learners of English as a foreign language. The Open Applied Linguistics Journal, 2, 1-10.

Premise Journal Vol 7 No 1, April 2018, e-ISSN: 2442-482x, p-ISSN: 2089-3345, page:1-21

Copyright@2018 by PJEE 
Noels, K., Pelletier, L., and Clement, R. (2003) Why Are You Learning a Second Language? Motivational orientations and self-determination theory. Language Learning 53 (1), 33-64.

Nulty, D. D. (2008). The adequacy of response rates to online and paper surveys: what can be done? Assessment and Evaluation in Higher Education 33 (3), pp. 301-314.

Pae, T. (2016) Effects of the differences between native and non-native Englishspeaking teachers on students' attitudes and motivation toward learning English, Asia Pacific Journal of Education, 1-16.

Phillipson, R. (1992). Linguistic Imperialism. Oxford: Oxford University Press. Ryan, M. R and Deci, E. L (2000) Intrinsic and Extrinsic Motivations: Classic Definitions and New Directions, Contemporary Educational Psychology 25, 54-67.

Samimy, K. K. and Brutt-Griffler, J. (1999). To be a native or non-native speaker: Perceptions of "non-native" students in a graduate TESOL program. In G. Braine (ed.), Non-Native Educators in English Language Teaching, 127-144. Mahwah: Lawrence Erlbaum.

Symonds, J. and Gorard, S. (2010). The death of mixed methods? Or the rebirth of research as craft, Evaluation and Research in Education, 23 (2), 121-36.

Takada, T. (2000). Sociopolitical concerns: The social status of LI Japanese EFL teachers. TESOL Matters, 10 (3), 